\title{
Thermal decomposition of 1-chloropropane behind the reflected shock waves in the temperature range of 1015-1220 K: Single pulse shock tube and computational studies
}

\author{
G SUDHAKAR and B RAJAKUMAR* \\ Department of Chemistry, Indian Institute of Technology Madras, Chennai 600 036, India \\ e-mail: rajakumar@iitm.ac.in
}

MS received 30 December 2013; revised 21 March 2014; accepted 25 May 2014

\begin{abstract}
The thermal decomposition of 1-chloropropane in argon was studied behind reflected shock waves in a single pulse shock tube over the temperature range of 1015-1220 K. The reaction mainly goes through unimolecular elimination of $\mathrm{HCl}$. The major products observed in the decomposition are propylene and ethylene, while the minor products identified are methane and propane. The rate constant for $\mathrm{HCl}$ elimination in the studied temperature range is estimated to be $\mathrm{k}(1015-1220 \mathrm{~K})=1.63 \times 10^{13} \exp \left(-(60.1 \pm 1.0) \mathrm{kcal} \mathrm{mol}^{-1} / \mathrm{RT}\right)$ $\mathrm{s}^{-1}$. The DFT calculations were carried out to identify the transition state(s) for the major reaction channel; and rate coefficient for this reaction is obtained to be $\mathrm{k}(800-1500 \mathrm{~K})=5.01 \times 10^{14} \exp \left(-(58.8) \mathrm{kcal} \mathrm{mol}^{-1} / \mathrm{RT}\right)$ $\mathrm{s}^{-1}$. The results are compared with the experimental findings.
\end{abstract}

Keywords. 1-chloropropane; SPST; simulations and DFT studies.

\section{Introduction}

Halogen-containing molecules have been extensively used in industrial as well as in domestic applications. Some of them have been used as propellants, solvents, and refrigerants. However, anthropogenic release of these compounds into the environment can have adverse effects such as stratospheric ozone depletion. Such problems can be reduced by minimizing the production of these molecules and also by destroying the leftouts. A complete knowledge of decomposition and the associated reactions is necessary if one chooses incineration as a method of destruction. ${ }^{1-4}$ Therefore, it is essential to understand the complete mechanism of dissociation of anthropogenically released compounds. In case of halogenated compounds, the dissociation usually initiated via unimolecular elimination of $\mathrm{HX}(\mathrm{X}=\mathrm{F}, \mathrm{Cl})$ and then the $\mathrm{C}-\mathrm{C}$ bond dissociation dominates with temperature. 1-Chloropropane is one such molecule, which can show adverse effects on the Earth's atmospheric chemical composition. The gas-phase unimolecular elimination of hydrogen chloride from 1-chloropropane has been studied experimentally by many research groups. ${ }^{5-9}$

$$
\mathrm{CH}_{3} \mathrm{CH}_{2} \mathrm{CH}_{2} \mathrm{Cl} \rightarrow \mathrm{CH}_{3} \mathrm{CH}=\mathrm{CH}_{2}+\mathrm{HCl}
$$

Barton et al. ${ }^{5}$ have used Pyrex glass reactor for studying the reaction $\mathrm{R} 1$ and reported the rate coefficient to

\footnotetext{
*For correspondence
}

be $\mathrm{k}_{1}=2.82 \times 10^{13} \exp \left(-(55.0 \pm 1.2) \mathrm{kcal} \mathrm{mol}^{-1} / \mathrm{RT}\right)$ $\mathrm{s}^{-1}$ over the temperature range of 693-751 K. Hartmann et $a l .{ }^{6}$ used static pyrolysis method and reported the rate coefficient for the reaction $\mathrm{R} 1$ to be $\mathrm{k}_{1}=3.16 \times$ $10^{13} \exp \left(-(55.1 \pm 0.7) \mathrm{kcal} \mathrm{mol}^{-1} / \mathrm{RT}\right) \mathrm{s}^{-1}$ over the temperature range of $672-734 \mathrm{~K}$ and the pressure range of 358-429 Torr. Evans et al. ${ }^{7}$ have also investigated the reaction R1 using single-pulse shock tube (SPST) technique and obtained the rate coefficient to be $\mathrm{k}_{1}=$ $3.09 \times 10^{13} \exp \left(-(54.4 \pm 1.1) \mathrm{kcal} \mathrm{mol}^{-1} / \mathrm{RT}\right) \mathrm{s}^{-1}$ over the temperature range of $960-1100 \mathrm{~K}$ and the pressure range of 5,370-5,850 Torr. Okada et al. ${ }^{8}$ have reported absolute rate coefficient for $\mathrm{R} 1$ to be $\mathrm{k}_{1}=$ $2.75 \times 10^{13} \exp \left(-(54.8 \pm 1.3) \mathrm{kcal} \mathrm{mol}^{-1} / \mathrm{RT}\right) \mathrm{s}^{-1}$ by using SPST technique over the temperature range of 990-1100 K. Recently, Saheb ${ }^{9}$ has studied the modified strong collision/RRKM theory to calculate the rate constant for unimolecular elimination of $\mathrm{HCl}$ as a function of pressure and temperature, and reported the rate coefficient to be $\mathrm{k}_{1}=3.16 \times 10^{14} \exp (-(59.7 \mathrm{kcal}$ $\left.\mathrm{mol}^{-1} / \mathrm{RT}\right) \mathrm{s}^{-1}$. In all the above studies, only unimolecular elimination of $\mathrm{HCl}$ was reported. The formation of other products like methane, ethylene and propane was never addressed.

In the present investigation, we report the complete decomposition mechanism of 1-chloropropane in the temperature range of 1015-1220 K. A SPST was built and used in the present investigation. In addition, the rate coefficient for the reaction R1 was obtained by DFT calculations and the results are presented here. 


\section{Experimental}

\subsection{The SPST facility}

2.1a Establishment of the single pulse shock tube (SPST): A SPST was established in our research laboratory at IIT Madras to investigate the decomposition studies of halogenated hydrocarbons, fossil fuels, biogenic compounds and alternative bio-fuels in the temperature range of $750-2000 \mathrm{~K}$. The shock tube was made with dural aluminium. An aluminium rod of $100 \mathrm{~mm}$ diameter was used to make small segments of $\sim 600 \mathrm{~mm}$ length. Each segment was bored to $50.8 \mathrm{~mm}$ internal diameter. These bored segments were honed to $10 \mu \mathrm{m}$ smoothness on the internal walls. This smoothness ensures an uninterrupted progress and passage of the generated shock wave.

The shock tube consists of a driver and a driven section separated by an aluminium diaphragm. The small segments fabricated (as described earlier) were used to make a $3405 \mathrm{~mm}$ length driven section and $1250 \mathrm{~mm}$ length driver section. The ratio of the driven to the driver section is 2.7. A manually operated ball valve was mounted at $558 \mathrm{~mm}$ distance from the end of the driven section. The diaphragm station, to host an aluminium diaphragm, was made with stainless steel and was used to connect the driver and driven sections. A conical dump tank with 10 liters of volume was connected at $45^{\circ}$ angle near the diaphragm station, on the driven section. A total of three pressure transducers (PCB-113A22) were mounted on the driven section of the shock tube to monitor the progress, attenuation (if any) of the shock wave. The temporal profile of the primary and the reflected shock wave in the reaction zone were followed using the pressure transducer mounted very close to the end of the driven section. The time taken to travel a known distance (the distance between any two transducers) was recorded using a universal time counter (Agilent 53131A) and the temporal profile of the shock wave recorded using a Digital Storage Oscilloscope (Agilent DSO-X 2002A). The whole shock tube was mounted at $1200 \mathrm{~mm}$ height from the ground on adjustable mechanical stands. The schematic diagram of the in-built SPST is given in figure 1.

The shock waves are generated by rupturing a prescored circular aluminium diaphragm with helium as a driver gas. The depth to which the diaphragm is scored depends on the targeted reflected shock strength and thereby temperature. The generated shock wave travels in the driven section and heats the test molecules. The primary shock wave gets reflected at the end flange and travels back towards the driver section and further heats the pre-heated test molecules. The dump tank helps in trapping most of the reflected shock wave. A typical temporal profile obtained in our in-built shock tube is shown in figure 2 . The reaction times are usually varied between 500 and $700 \mu$ s in our experiments.

The shock tube was calibrated using both nitrogen $\left(\mathrm{N}_{2}\right)$ and helium $(\mathrm{He})$ as driver gases and argon $(\mathrm{Ar})$ as driven gas. The calibration of the shock tube was carried out mainly to ensure that the experimentally measured ratios of pressures in various zones in the shock tube are comparable with the theoretically computed ones. The agreement between the experimentally measured and theoretically computed values was found to be excellent.

\section{$2.1 \mathrm{~b}$ Determination of reflected shock temperature}

$\left(T_{5}\right)$ : In the shock tube experiments, determination of the exact temperature generated by the reflected shock wave is a difficult task. Direct measurement of the temperature is difficult. However, one can estimate the temperature of the reflected shock wave using the

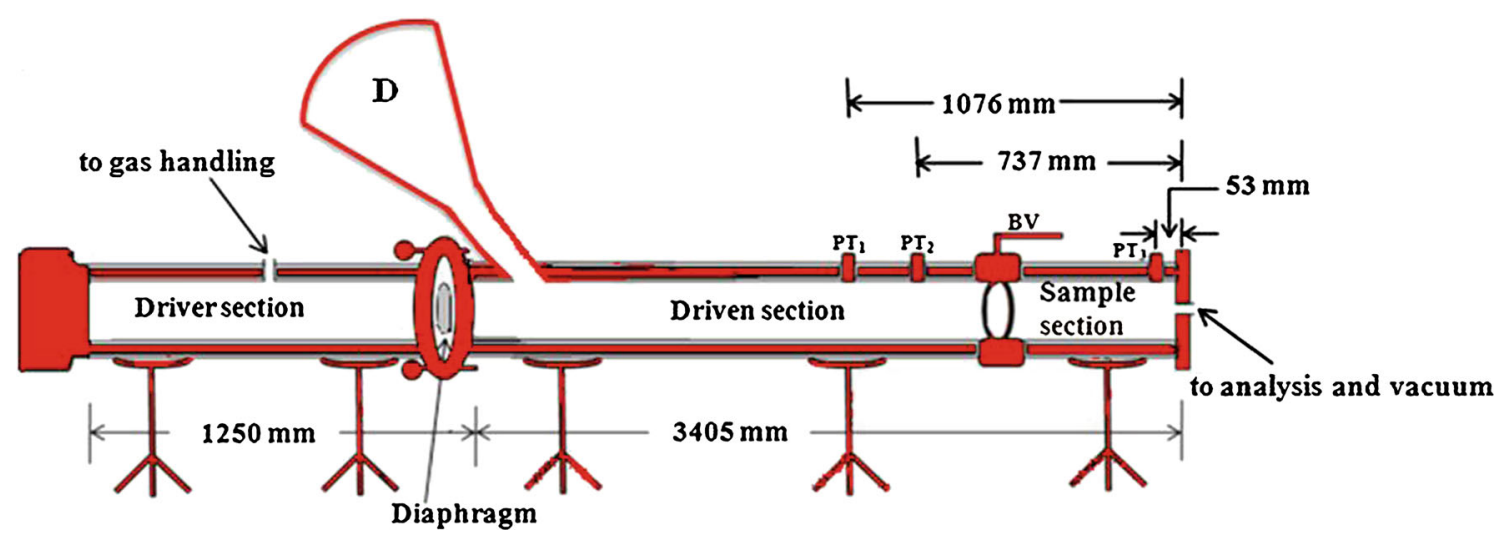

Figure 1. The schematic diagram of the Single Pulse Shock Tube (SPST) used in the present investigation: $\mathrm{PT}_{1}, \mathrm{PT}_{2}$ and $\mathrm{PT}_{3}$ are Pressure transducers, BV- ball valve and D-dump tank. 


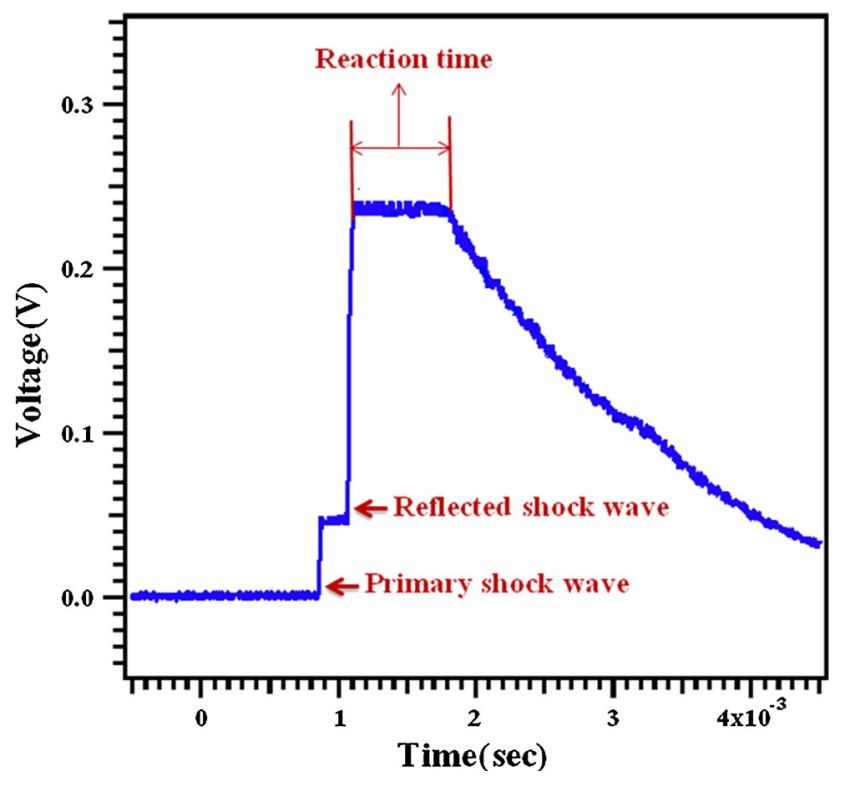

Figure 2. A typical pressure trace recorded by an oscilloscope showing the arrival of primary, reflected shock waves and expansion wave.

principles of conservation of mass and energy by using the following equation. ${ }^{10}$

$$
\left|\frac{T_{5}}{T_{1}}=\frac{\left\{2(\gamma-1) M_{1}^{2}+(3-\gamma)\right\}\left\{(3 \gamma-1) M_{1}^{2}-2(\gamma-1)\right\}}{(\gamma+1)^{2} M_{1}^{2}}\right|
$$

Where $T_{5}$ and $T_{1}$ are reflected shock temperature and initial temperature, respectively, $\gamma$ is specific heat ratio and $M_{1}$ is incident shock Mach number. In this method, the determined primary and reflected shock temperatures are proven to be unrealistic for several reasons such as real gas effects, boundary layer effects and exo or endothermicity of the chemical reactions. To estimate the actual temperature, many research groups used a chemical thermometric method.

2.1c Chemical thermometric method: In this method, a known reaction is carried out along with the reaction of interest, in the same experiment. The temperature behind the reflected shock wave, $T_{5}$, is determined from the extent of decomposition of the reference compound (cyclohexene in our case), which is added to the reaction sample to serve as internal standard. Cyclohexene decomposes into $\mathrm{CH}_{2}=\mathrm{CH}-\mathrm{CH}=\mathrm{CH}_{2}+\mathrm{CH}_{2}=\mathrm{CH}_{2}$. The rate constant for the decomposition of cyclohexene to $\mathrm{CH}_{2}=\mathrm{CH}-\mathrm{CH}=\mathrm{CH}_{2}+\mathrm{CH}_{2}=\mathrm{CH}_{2}$ was reported by Tsang $^{11}$ to be $\mathrm{k}=1.047 \times 10^{15} \exp (-66.7 \mathrm{kcal}$ $\left.\mathrm{mol}^{-1} / \mathrm{RT}\right) \mathrm{s}^{-1}$. Recently, Stranic et al. ${ }^{12}$ have reported this rate coefficient to be $\mathrm{k}=4.84 \times 10^{14} \exp (-63.4 \mathrm{kcal}$ $\left.\mathrm{mol}^{-1} / \mathrm{RT}\right) \mathrm{s}^{-1}$. We have used this rate coefficient also in our calculations. Reflected shock temperatures were calculated from the following relation.

$$
T=-\left(\frac{E}{R}\right) /\left[\ln \left\{-\frac{1}{A t} \ln (1-\chi)\right\}\right]
$$

Where $t$ is the reaction time, $\mathrm{A}$ and $\mathrm{E}$ are the Arrhenius parameters of the decomposition of internal standard and $\chi$ is the extent of decomposition defined as

$$
\chi=\frac{\left[\mathrm{CH}_{2}=\mathrm{CH}-\mathrm{CH}=\mathrm{CH}_{2}\right]_{t}}{\left[\mathrm{CH}_{2}=\mathrm{CH}-\mathrm{CH}=\mathrm{CH}_{2}\right]_{t}+\left[\mathrm{c}-\mathrm{C}_{6} \mathrm{H}_{10}\right]_{t}}
$$

About $28 \mathrm{~K}$ difference was found between the temperatures calculated using the rate coefficients reported by Tsang $^{11}$ and Stranic et al. ${ }^{12}$

\subsection{Materials}

The 1-chloropropane (Sigma Aldrich) was purified through distillation to a minimum purity of $99.8 \%$. The sample was further purified by freeze-pumpthaw method, for several times before using the sample in our experiments. Cyclohexene (Sigma Aldrich, $>99.0 \%$ ), methane (Praxair, >99.5\%), ethylene (Praxair, >99.5\%), propylene (Praxair, >99.5\%), propane (Praxair, $>99.5 \%$ ), helium (Praxair, UHP grade) and argon (Praxair, UHP grade) were used without further purification.

\subsection{Analytical methods}

The post-shock mixtures were analyzed by two techniques, viz. gas chromatography and FT-IR spectroscopy. While the gas chromatographic technique was used for quantitative analysis, FT-IR spectroscopy was used for qualitative analysis. The post-shock mixtures were withdrawn from the port located at the end of shock tube into an aluminium sample cell (for gas chromatographic analysis) and into an IR cell made with $\mathrm{KBr}$ windows (for FT-IR spectroscopic analysis). The postshocked gas samples were analyzed in gas chromatograph (Agilent $6890 \mathrm{~N}$ ) by injecting $0.5 \mathrm{~mL}$ through a six-port online gas-sampling valve into a Porapak-Q column and oven temperature was programmed from $75^{\circ} \mathrm{C}$ to $150^{\circ} \mathrm{C}$. Nitrogen was used as a carrier gas in the analysis. The sensitivity of the flame ionization detector (FID) towards all the reactants and products were calibrated over a known range of concentrations. The left-out reactant and other products were quantified using the sensitivity factors obtained in the calibration and the areas under each peak. The qualitative analysis of the post-shock samples were carried out by loading 760 Torr of the sample into a gas sample 


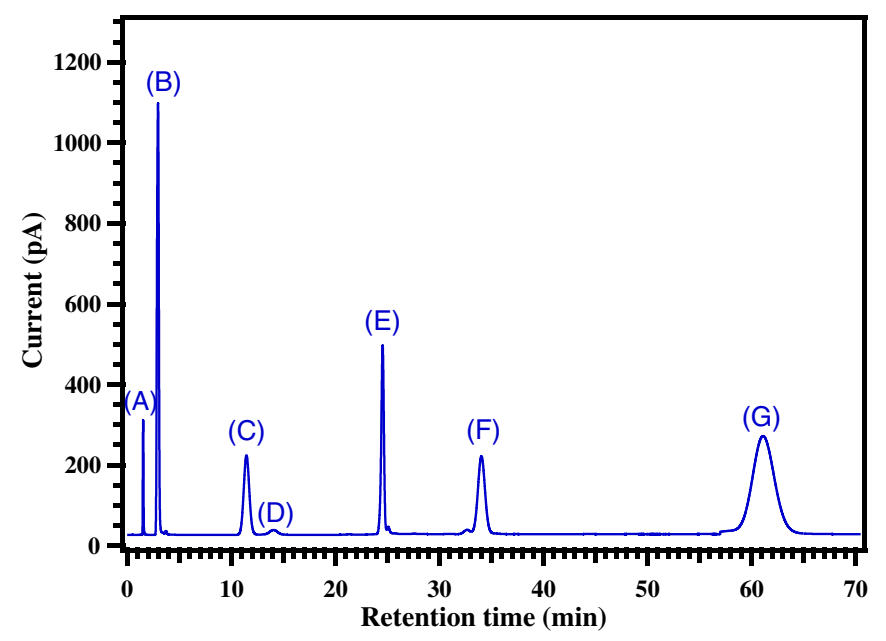

Figure 3. Gas chromatogram of a post shock mixture of 1-chloropropane obtained for an experiment carried out at $1172 \mathrm{~K}$ : The peaks labeled (A) methane, (B) ethylene, $(\mathrm{C})$ propylene, (D) propane $(\mathrm{E})$ 1,3- butadiene, $(\mathrm{F}) 1$ chloropropane, and $(\mathrm{G})$ cyclohexene.

cell made with $\mathrm{KBr}$ windows, which was housed in an FT-IR spectrometer (BRUKER VERTEX 70). A representative chromatogram and IR spectrum obtained for the post-shock sample, where the reflected shock temperatures were $1172 \mathrm{~K}$ and $1152 \mathrm{~K}$, respectively, are given in figures 3 and 4, respectively.

\subsection{Experimentation}

The SPST was evacuated using a diffusion pump and flushed two to three times with argon before carrying out each experiment. In each experiment, 10 Torr of 1-chloropropane and 20 Torr of cyclohexene (internal standard) were loaded into the sample chamber by using Baratron pressure gauge, after closing the ball valve. These samples were further diluted with argon until a desired pressure was reached. The section between the ball valve and the diaphragm of driven section was filled only with argon to a slightly larger pressure (10 Torr higher) than the sample chamber to avoid back diffusion of the test sample. In all experiments, pressure $(P 1)$ was varied between 100 and 750 Torr, depending on the temperature required. The pressures $P_{5}$, behind the reflected shock waves were calculated using ideal shock Mach relations. $\mathrm{P}_{5}$ varied between 10 and $20 \mathrm{~atm}$. After each experiment, the post-shock mixture was analyzed using gas chromatographic and spectroscopic methods, as mentioned before. The concentrations of each species are calculated using peak area and sensitivity factors corresponding to individual species. Concentrations of all the reactants and products are expressed in terms of mole fractions, after normalization. It should be noted here that ethylene is formed not only in the decomposition of 1-chloropropane but also in the degradation of cyclohexene. Cyclohexene decomposes into equal quantities of 1,3-butadiene and ethylene. ${ }^{11}$
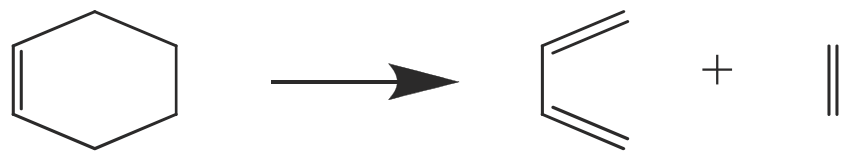

1, 3-Butadiene does not decompose in the temperature range of the current investigation ${ }^{11}(1015-1220 \mathrm{~K})$. Knowing the concentration of 1,3-butadiene, an equal amount of ethylene was subtracted from the total concentration of measured ethylene to obtain the actual

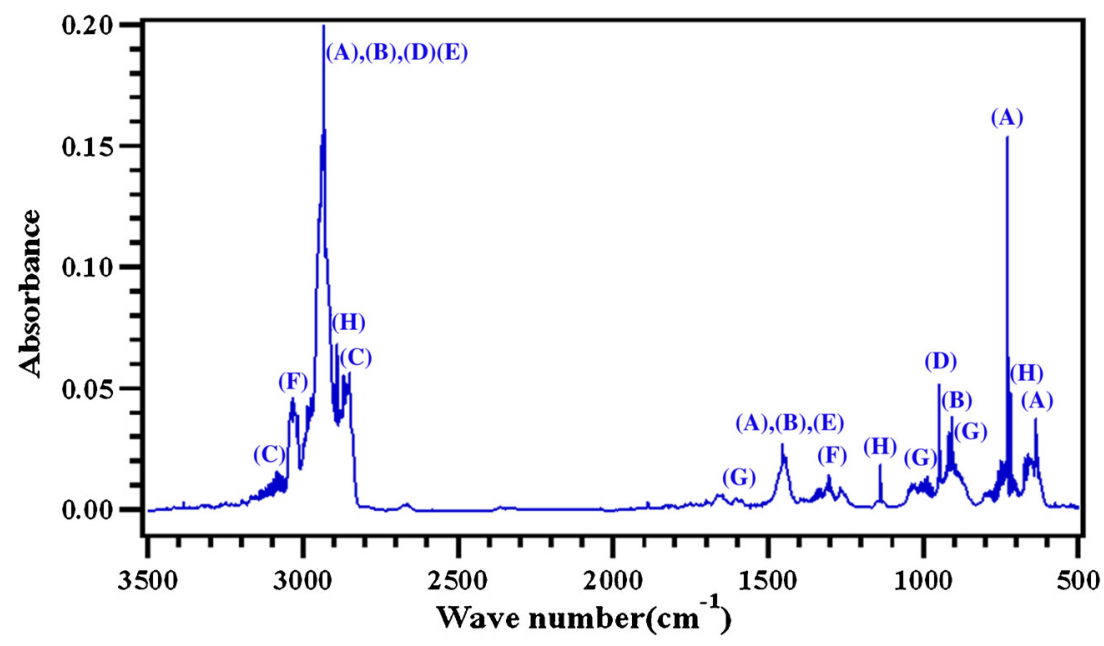

Figure 4. Infrared spectrum of the post-shock mixture of the experiment carried out at $1152 \mathrm{~K}$. The peaks assigned are (A) 1-chloropropane (B) propylene, $(\mathrm{C}) \mathrm{HCl}(\mathrm{D})$ ethylene, $(\mathrm{E})$ propane, $(\mathrm{F})$ methane, $(\mathrm{G})$ 1,3-Butadiene and (H) cyclohexene. 
concentration of ethylene formed only due to the reactant 1-chloropropane. Details of the experimental conditions and the distribution of concentrations of reaction species are given in table 1.

\section{Results and discussion}

\subsection{Experimental results and discussion}

To determine the distribution of reaction products, around 39 experiments were carried out with 10 Torr of 1-chloropropane and 20 Torr of cyclohexene (internal standard) in argon, covering the temperature range of 1015-1220 K. In our analysis, all products, namely methane, ethylene and propylene, were observed at all temperatures except propane, which was observed above $1110 \mathrm{~K}$, (cf. table 1). Insignificant amount of ethane was also formed in the decomposition process. However, it was not quantified due to its very low concentration, below the detection limits of both the analytical tools. The rate coefficient was calculated using the following equation. The rate coefficient calculated was used to plot the Arrhenius plot for the elimination of $\mathrm{HCl}$ and is given in figure 5 .

$$
k=\frac{1}{t} \ln \left(\frac{\left[\mathrm{CH}_{3} \mathrm{CH}_{2} \mathrm{CH}_{2} \mathrm{Cl}_{0}\right.}{\left[\mathrm{CH}_{3} \mathrm{CH}_{2} \mathrm{CH}_{2} \mathrm{Cl}\right]_{0}-\left[\mathrm{CH}_{3} \mathrm{CH}=\mathrm{CH}_{2}\right]_{t}}\right)
$$

Where $\left[\mathrm{CH}_{3} \mathrm{CH}_{2} \mathrm{CH}_{2} \mathrm{Cl}\right]_{0}$ and $\left[\mathrm{CH}_{3} \mathrm{CH}=\mathrm{CH}_{2}\right]_{t}$ are initial concentration of $\mathrm{CH}_{3} \mathrm{CH}_{2} \mathrm{CH}_{2} \mathrm{Cl}$ and concentration of $\mathrm{CH}_{3} \mathrm{CH}=\mathrm{CH}_{2}$ at reaction time $t$, respectively. The data were fit with linear least squares method and the

Table 1. Experimental conditions and product distribution in the decomposition of 1-chloropropane.

\begin{tabular}{|c|c|c|c|c|c|c|c|}
\hline S.No & $\mathrm{T}_{5}(\mathrm{~K})$ & $\begin{array}{l}\text { Reaction } \\
\text { time }(\mu \mathrm{s})\end{array}$ & $\begin{array}{c}{\left[\mathrm{CH}_{4}\right]_{t} /} \\
{\left[\mathrm{C}_{3} \mathrm{H}_{7} \mathrm{Cl}\right]_{0}}\end{array}$ & $\begin{array}{c}{\left[\mathrm{C}_{2} \mathrm{H}_{4}\right]_{t} /} \\
{\left[\mathrm{C}_{3} \mathrm{H}_{7} \mathrm{Cl}\right]_{0}}\end{array}$ & $\begin{array}{c}{\left[\mathrm{C}_{3} \mathrm{H}_{6}\right]_{t} /} \\
{\left[\mathrm{C}_{3} \mathrm{H}_{7} \mathrm{Cl}\right]_{0}}\end{array}$ & $\begin{array}{c}{\left[\mathrm{C}_{3} \mathrm{H}_{8}\right]_{t} /} \\
{\left[\mathrm{C}_{3} \mathrm{H}_{7} \mathrm{Cl}\right]_{0}}\end{array}$ & $\begin{array}{l}{\left[\mathrm{C}_{3} \mathrm{H}_{7} \mathrm{Cl}\right]_{t} /} \\
{\left[\mathrm{C}_{3} \mathrm{H}_{7} \mathrm{Cl}\right]_{0}}\end{array}$ \\
\hline 1 & 1016 & 206 & 0.000121 & 0.000143 & 0.000413 & 0.000000 & 0.999323 \\
\hline 2 & 1061 & 192 & 0.000223 & 0.000626 & 0.001404 & 0.000000 & 0.997746 \\
\hline 3 & 1063 & 218 & 0.000219 & 0.000458 & 0.001562 & 0.000000 & 0.997761 \\
\hline 4 & 1075 & 201 & 0.000340 & 0.000754 & 0.002047 & 0.000000 & 0.996859 \\
\hline 5 & 1076 & 213 & 0.000254 & 0.000811 & 0.002244 & 0.000000 & 0.996691 \\
\hline 6 & 1113 & 448 & 0.001167 & 0.005964 & 0.011510 & 0.000111 & 0.981359 \\
\hline 7 & 1116 & 308 & 0.001205 & 0.004305 & 0.009401 & 0.000000 & 0.985088 \\
\hline 8 & 1119 & 264 & 0.001022 & 0.004068 & 0.008118 & 0.000000 & 0.986792 \\
\hline 9 & 1120 & 448 & 0.001526 & 0.007193 & 0.01367 & 0.000213 & 0.977610 \\
\hline 10 & 1122 & 544 & 0.001833 & 0.009478 & 0.01590 & 0.000279 & 0.972789 \\
\hline 11 & 1123 & 277 & 0.001022 & 0.005266 & 0.012096 & 0.000000 & 0.981617 \\
\hline 12 & 1127 & 632 & 0.005581 & 0.021296 & 0.021078 & 0.001043 & 0.952045 \\
\hline 13 & 1128 & 468 & 0.001957 & 0.010637 & 0.017509 & 0.000292 & 0.969896 \\
\hline 14 & 1129 & 583 & 0.017089 & 0.029814 & 0.020241 & 0.001007 & 0.931849 \\
\hline 15 & 1137 & 322 & 0.001728 & 0.008289 & 0.01581 & 0.000160 & 0.974173 \\
\hline 16 & 1142 & 377 & 0.001894 & 0.009305 & 0.024346 & 0.000176 & 0.964455 \\
\hline 17 & 1143 & 475 & 0.002727 & 0.015889 & 0.021237 & 0.000680 & 0.960147 \\
\hline 18 & 1145 & 320 & 0.002519 & 0.011302 & 0.016786 & 0.000396 & 0.969393 \\
\hline 19 & 1153 & 513 & 0.010438 & 0.032408 & 0.032418 & 0.001813 & 0.922923 \\
\hline 20 & 1154 & 612 & 0.010655 & 0.044864 & 0.045470 & 0.002259 & 0.896753 \\
\hline 21 & 1155 & 607 & 0.008600 & 0.036563 & 0.032627 & 0.002159 & 0.920051 \\
\hline 22 & 1156 & 496 & 0.006054 & 0.028749 & 0.031453 & 0.001957 & 0.933744 \\
\hline 23 & 1158 & 513 & 0.010065 & 0.042968 & 0.033604 & 0.002088 & 0.911275 \\
\hline 24 & 1159 & 597 & 0.006876 & 0.028651 & 0.019381 & 0.001555 & 0.943537 \\
\hline 25 & 1161 & 373 & 0.004835 & 0.024043 & 0.034504 & 0.00101 & 0.936618 \\
\hline 26 & 1162 & 515 & 0.016563 & 0.055813 & 0.048322 & 0.00241 & 0.876893 \\
\hline 27 & 1163 & 746 & 0.039215 & 0.155742 & 0.058959 & 0.005412 & 0.740672 \\
\hline 28 & 1164 & 437 & 0.014277 & 0.081571 & 0.048066 & 0.002051 & 0.856085 \\
\hline 29 & 1166 & 485 & 0.014957 & 0.068194 & 0.040649 & 0.003387 & 0.872813 \\
\hline 30 & 1166 & 600 & 0.019382 & 0.083371 & 0.063776 & 0.004093 & 0.829378 \\
\hline 31 & 1167 & 700 & 0.026921 & 0.089550 & 0.074231 & 0.004526 & 0.804772 \\
\hline 32 & 1169 & 586 & 0.026110 & 0.093592 & 0.061837 & 0.004229 & 0.814233 \\
\hline 33 & 1170 & 550 & 0.023694 & 0.091367 & 0.054488 & 0.004777 & 0.825674 \\
\hline 34 & 1172 & 653 & 0.038163 & 0.142641 & 0.077478 & 0.005113 & 0.736605 \\
\hline 35 & 1173 & 688 & 0.041753 & 0.172779 & 0.067325 & 0.00512 & 0.713024 \\
\hline 36 & 1181 & 646 & 0.048500 & 0.191200 & 0.087586 & 0.005947 & 0.666767 \\
\hline 37 & 1193 & 476 & 0.004174 & 0.008134 & 0.062851 & 0.000000 & 0.924842 \\
\hline 38 & 1198 & 545 & 0.128583 & 0.235474 & 0.104557 & 0.003762 & 0.527624 \\
\hline 39 & 1210 & 548 & 0.045388 & 0.142288 & 0.187067 & 0.005913 & 0.619344 \\
\hline
\end{tabular}




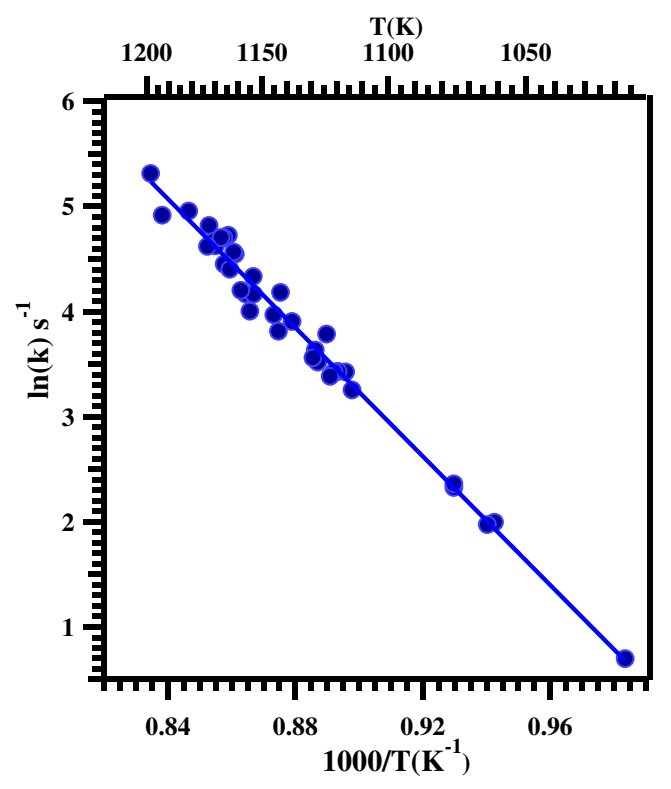

Figure 5. The Arrhenius plot of the rate coefficients obtained for the unimolecular elimination of $\mathrm{HCl}$ from 1chloropropane, from the experiments carried out behind the reflected shock waves in SPST facility in the temperature range of $1015-1220 \mathrm{~K}$.

rate coefficient for the unimolecular elimination of $\mathrm{HCl}$ from 1-chloropropane is obtained to be $\mathrm{k}=1.63 \times$ $10^{13} \exp (-(60.1 \pm 1.0) / \mathrm{RT}) \mathrm{s}^{-1}$, where the activation energy is in $\mathrm{kcal} \mathrm{mol}^{-1}$. The obtained rate parameters for the unimolecular elimination of $\mathrm{HCl}$ from the 1chloropropane in the present study follows the general patterns that have been observed in earlier shock tube studies ${ }^{13}$ involving four-centre molecular elimination processes and there is a possibility of $\mathrm{C}-\mathrm{Cl}$ and $\mathrm{C}-$ $\mathrm{C}$ bond dissociation in 1-chloropropane, which is the only way the formation of the other products can be explained.

\subsection{Kinetic simulations}

To observe the product distribution and to understand the complete decomposition mechanism, a reaction scheme has been proposed and the computer simulations are performed. The proposed reaction scheme is brought together under the same condition as those used in the laboratory experiments and to find the concentration with respect to reaction time and temperatures. The reaction scheme containing 28 reactions and 22 species was proposed for the simulation of all the species, and is given in table 2. The kinetic simulations were performed using IBM chemical kinetics simulator 1.0.

To perform simulations, the pre-exponential factor, activation energy and temperature dependence for elementary reactions involved in the proposed reaction mechanism were taken from literature except for reaction R1 (from this work). The reflected shock temperature obtained using chemical thermometry and reaction times obtained from each experiment were used in the kinetic simulations. The simulated profiles for all the species were found to be in good agreement with experimentally obtained profiles. The concentration profiles for all the species were compared with experimental results, and are shown in figure 6.

The same reaction numbers given in the proposed mechanism are used in the text for discussion. (Here the reaction numbers are used throughout the manuscript corresponding to the list in table 2). As far as of our knowledge is concerned, the rate coefficient for the $\mathrm{C}$ $\mathrm{Cl}$ bond scission in 1-chloropropane (R2) is not available in the literature. To account for this reaction, the rate coefficient reported for $\mathrm{CH}_{3} \mathrm{CH}_{2} \mathrm{Cl} \rightarrow \mathrm{CH}_{3} \mathrm{CH}_{2}+$ $\mathrm{Cl}$ reaction ${ }^{14}$ was taken as reference and an activation energy of $77.0 \mathrm{kcal} \mathrm{mol}^{-1}$ was used instead of $83.0 \mathrm{kcal}$ $\mathrm{mol}^{-1}$ considering the fact that an additional $\mathrm{CH}_{3}$ group would reduce the barrier by about $5-6 \mathrm{kcal} \mathrm{mol}^{-1}$. Similarly, the rate coefficients for $\mathrm{CH}_{3} \mathrm{CH}_{2} \mathrm{CH}_{2} \mathrm{Cl} \rightarrow \mathrm{CH}_{3}+$ $\mathrm{CH}_{2} \mathrm{CH}_{2} \mathrm{Cl}$ (R8) and $\mathrm{CH}_{3} \mathrm{CH}_{2} \mathrm{CH}_{2} \mathrm{Cl} \rightarrow \mathrm{CH}_{3} \mathrm{CH}_{2}+$ $\mathrm{CH}_{2} \mathrm{Cl}$ (R10) reactions are also unavailable. The rate coefficient for $\mathrm{CH}_{3} \mathrm{CH}_{2} \mathrm{Cl} \rightarrow \mathrm{CH}_{3}+\mathrm{CH}_{2} \mathrm{Cl}$ was used for both R8 and R10 in our simulations.

3.2a Methane: Methane is formed directly from either molecular dissociation of propylene or $\mathrm{C}-\mathrm{C}$ bond dissociation in propyl radical, followed by the reaction between $\mathrm{CH}_{3}, \mathrm{H}_{2}$ and $\mathrm{CH}_{3} \mathrm{CH}_{2}, \mathrm{CH}_{3}$

$$
\begin{aligned}
\mathrm{CH}_{3} \mathrm{CH} & =\mathrm{CH}_{2} \rightarrow \mathrm{CH}_{4}+\mathrm{HC} \equiv \mathrm{CH} \\
\mathrm{k} & =3.5 \times 10^{12} \exp (-70.0 / \mathrm{RT})
\end{aligned}
$$

$$
\begin{aligned}
\mathrm{CH}_{3} \mathrm{CH}_{2} \mathrm{CH}_{2} & \rightarrow \mathrm{CH}_{3}+\mathrm{CH}_{2}=\mathrm{CH}_{2} \\
\mathrm{k} & =1.26 \times 10^{13} \exp (-30.4 / \mathrm{RT})
\end{aligned}
$$

$$
\begin{aligned}
\mathrm{CH}_{3}+\mathrm{H}_{2} & \rightarrow \mathrm{CH}_{4}+\mathrm{H} \\
\mathrm{k} & =6.5 \times 10^{2}(\mathrm{~T})^{3} \exp (-7.6 / \mathrm{RT})
\end{aligned}
$$

$$
\begin{aligned}
\mathrm{CH}_{3} \mathrm{CH}_{2}+\mathrm{CH}_{3} & \rightarrow \mathrm{CH}_{4}+\mathrm{CH}_{2}=\mathrm{CH}_{2} \\
\mathrm{k} & =9.80 \times 10^{12}(\mathrm{~T})^{-0.5}
\end{aligned}
$$

The contribution of reaction R20 and R27 depends on the available concentrations of the methyl and ethyl radicals. Contributions from both of these reactions were found to be small, but they were included for completeness. The reaction of $\mathrm{CH}_{3}$ with $\mathrm{CH}_{3} \mathrm{CH}_{2} \mathrm{CH}_{2} \mathrm{Cl}$ was 
Table 2. The reaction scheme proposed for the thermal decomposition of 1-chloropropane.

\begin{tabular}{|c|c|c|c|}
\hline Reaction No & Reaction & Rate coefficient $(\mathrm{k})^{\mathrm{a}, \mathrm{b}}$ & Reference \\
\hline R1 & $\mathrm{CH}_{3} \mathrm{CH}_{2} \mathrm{CH}_{2} \mathrm{Cl} \rightarrow \mathrm{CH}_{3} \mathrm{CH}_{2}=\mathrm{CH}_{2}+\mathrm{HCl}$ & $\mathrm{k}=1.63 \times 10^{13} \exp (-60.1 / \mathrm{RT})$ & This work \\
\hline R2 & $\mathrm{CH}_{3} \mathrm{CH}_{2} \mathrm{CH}_{2} \mathrm{Cl} \rightarrow \mathrm{CH}_{3} \mathrm{CH}_{2} \mathrm{CH}_{2}+\mathrm{Cl}$ & $\mathrm{k}=5.0 \times 10^{15} \exp (-76.9 / \mathrm{RT})$ & \\
\hline R3 & $\mathrm{CH}_{3} \mathrm{CH}_{2} \mathrm{CH}_{2} \rightarrow \mathrm{CH}_{3} \mathrm{CH}=\mathrm{CH}_{2}+\mathrm{H}$ & $\mathrm{k}=1.0 \times 10^{14} \exp (-37.4 / \mathrm{RT})$ & 15 \\
\hline R4 & $\mathrm{CH}_{3} \mathrm{CH}_{2} \mathrm{CH}_{2} \rightarrow \mathrm{CH}_{2}=\mathrm{CH}_{2}+\mathrm{CH}_{3}$ & $\mathrm{k}=1.26 \times 10^{13} \exp (-30.4 / \mathrm{RT})$ & 16 \\
\hline R5 & $\mathrm{CH}_{3}+\mathrm{H} \rightarrow \mathrm{CH}_{4}$ & $\mathrm{k}=6.33 \times 10^{-21}(\mathrm{~T})^{-2.98} \exp (-1.3 / \mathrm{RT})$ & 17 \\
\hline R6 & $\mathrm{CH}_{3} \mathrm{CH}_{2} \mathrm{CH}_{2}+\mathrm{CH}_{3} \rightarrow \mathrm{CH}_{4}+\mathrm{CH}_{3} \mathrm{CH}=\mathrm{CH}_{2}$ & $\mathrm{k}=1.90 \times 10^{-11} \exp (\mathrm{T})^{-0.32}$ & 18 \\
\hline R7 & $\mathrm{Cl}+\mathrm{Cl} \rightarrow \mathrm{Cl}_{2}$ & $\mathrm{k}=6.04 \times 10^{-34} \exp (-1.8 / \mathrm{RT})$ & 19 \\
\hline R8 & $\mathrm{CH}_{3} \mathrm{CH}_{2} \mathrm{CH}_{2} \mathrm{Cl} \rightarrow \mathrm{CH}_{3}+\mathrm{CH}_{2} \mathrm{CH}_{2} \mathrm{Cl}$ & $\mathrm{k}=1.71 \times 10^{16} \exp (-75.0 / \mathrm{RT})$ & 14 \\
\hline R9 & $\mathrm{CH}_{2} \mathrm{CH}_{2} \mathrm{Cl} \rightarrow \mathrm{CH}_{2}=\mathrm{CH}_{2}+\mathrm{Cl}$ & $\mathrm{k}=3.9 \times 10^{13} \exp (-21.7 / \mathrm{RT})$ & 20 \\
\hline R10 & $\mathrm{CH}_{3} \mathrm{CH}_{2} \mathrm{CH}_{2} \mathrm{Cl} \rightarrow \mathrm{CH}_{3} \mathrm{CH}_{2}+\mathrm{CH}_{2} \mathrm{Cl}$ & $\mathrm{k}=1.71 \times 10^{16} \exp (-75.0 / \mathrm{RT})$ & 14 \\
\hline R11 & $\mathrm{CH}_{2} \mathrm{Cl}+\mathrm{CH}_{2} \mathrm{Cl} \rightarrow \mathrm{ClCH}_{2}-\mathrm{CH}_{2} \mathrm{Cl}$ & $\mathrm{k}=3.56 \times 10^{-9}(\mathrm{~T})^{-0.85}$ & 21 \\
\hline R12 & $\mathrm{CH}_{3} \mathrm{CH}=\mathrm{CH}_{2}+\mathrm{H} \rightarrow \mathrm{CH}_{2}=\mathrm{CH}_{2}+\mathrm{CH}_{3}$ & $\mathrm{k}=4.34 \times 10^{-16}(\mathrm{~T})^{1.5} \exp (-2.0 / \mathrm{RT})$ & 22 \\
\hline R13 & $\mathrm{H}_{2}+\mathrm{CH}_{3} \rightarrow \mathrm{CH}_{4}+\mathrm{H}$ & $\mathrm{k}=1.45 \times 10^{-11} \exp (-13.5 / \mathrm{RT})$ & 23 \\
\hline R14 & $\mathrm{CH}_{3} \mathrm{CH}=\mathrm{CH}_{2}+\mathrm{CH}_{3} \rightarrow \mathrm{CH}_{4}+\mathrm{CH}_{2} \mathrm{CH}=\mathrm{CH}_{2}$ & $\mathrm{k}=3.68 \times 10^{-24}(\mathrm{~T})^{3.5} \exp (-5.7 / \mathrm{RT})$ & 24 \\
\hline R15 & $\mathrm{CH}_{3} \mathrm{CH}=\mathrm{CH}_{2} \rightarrow \mathrm{CH}_{4}+\mathrm{HC} \equiv \mathrm{CH}$ & $\mathrm{k}=3.50 \times 10^{12} \exp (-70.0 / \mathrm{RT})$ & 22 \\
\hline R16 & $\mathrm{CH}_{3}+\mathrm{CH}_{3} \mathrm{CH}_{2} \rightarrow \mathrm{CH}_{3} \mathrm{CH}_{2} \mathrm{CH}_{3}$ & $\mathrm{k}=2.45 \times 10^{14}(\mathrm{~T})^{-0.5}$ & 25 \\
\hline R17 & $\mathrm{CH}_{3}+\mathrm{HCl} \rightarrow \mathrm{CH}_{4}+\mathrm{Cl}$ & $\mathrm{k}=8.92 \times 10^{-13} \exp (-3.1 / \mathrm{RT})$ & 26 \\
\hline R18 & $\mathrm{CH}_{3}+\mathrm{CH}_{3} \mathrm{CH}_{2} \mathrm{CH}_{2} \mathrm{Cl} \rightarrow \mathrm{CH}_{4}+\mathrm{CH}_{2} \mathrm{CH}_{2} \mathrm{CH}_{2} \mathrm{Cl}$ & $\mathrm{k}=2.09 \times 10^{-12} \exp (-11.6 / \mathrm{RT})$ & 27 \\
\hline R19 & $\mathrm{CH}_{2} \mathrm{CH}_{2} \mathrm{CH}_{2} \mathrm{Cl} \rightarrow \mathrm{CH}_{2}=\mathrm{CH}_{2}+\mathrm{CH}_{2} \mathrm{Cl}$ & $\mathrm{k}=3.99 \times 10^{9}(\mathrm{~T})^{-5.61} \exp (-18.7 / \mathrm{RT})$ & 28 \\
\hline $\mathrm{R} 20$ & $\mathrm{CH}_{3} \mathrm{CH}_{2}+\mathrm{CH}_{3} \rightarrow \mathrm{CH}_{4}+\mathrm{C}_{2} \mathrm{H}_{4}$ & $\mathrm{k}=9.80 \times 10^{12}(\mathrm{~T})^{-0.5}$ & 25 \\
\hline $\mathrm{R} 21$ & $\mathrm{CH}_{2} \mathrm{CH}_{2} \mathrm{Cl} \rightarrow \mathrm{CH}_{2}=\mathrm{CHCl}+\mathrm{H}$ & $\mathrm{k}=1.40 \times 10^{13} \exp (-42.1 / \mathrm{RT})$ & 20 \\
\hline R22 & $\mathrm{CH}_{3+} \mathrm{CH}_{3} \rightarrow \mathrm{CH}_{3} \mathrm{CH}_{2}+\mathrm{H}$ & $\mathrm{k}=8.26 \times 10^{-12}(\mathrm{~T})^{0.1} \exp (-10.6 / \mathrm{RT})$ & 29 \\
\hline $\mathrm{R} 23$ & $\mathrm{HCl}+\mathrm{Cl} \rightarrow \mathrm{Cl}_{2}+\mathrm{H}$ & $\mathrm{k}=4.72 \times 10^{-10} \exp (-47.3 / \mathrm{RT})$ & 30 \\
\hline R24 & $\mathrm{CH}_{2} \mathrm{Cl}+\mathrm{HCl} \rightarrow \mathrm{CH}_{2} \mathrm{Cl}_{2}+\mathrm{H}$ & $\mathrm{k}=1.71 \times 10^{-22}(\mathrm{~T})^{2.85} \exp (-28.4 / \mathrm{RT})$ & 31 \\
\hline R25 & $\mathrm{CH}_{3}+\mathrm{CH}_{2} \mathrm{CH}=\mathrm{CH}_{2} \rightarrow \mathrm{CH}_{4}+\mathrm{CH}_{2}=\mathrm{C}=\mathrm{CH}_{2}$ & $\mathrm{k}=7.881 \times 10^{-12}(\mathrm{~T})^{-0.4} \exp (-0.1 / \mathrm{RT})$ & 24 \\
\hline R26 & $\mathrm{CH}_{3}+\mathrm{CH}_{3} \rightarrow \mathrm{C}_{2} \mathrm{H}_{4}+\mathrm{H}_{2}$ & $\mathrm{k}=9.9 \times 10^{15} \exp (-32.9 / \mathrm{RT})$ & 32 \\
\hline R27 & $\mathrm{CH}_{3}+\mathrm{H}_{2} \rightarrow \mathrm{CH}_{4}+\mathrm{H}$ & $\mathrm{k}=6.5 \times 10^{2}(\mathrm{~T})^{3} \exp (-7.6 / \mathrm{RT})$ & 15 \\
\hline $\mathrm{R} 28$ & $\mathrm{CH}_{3} \mathrm{CH}_{2} \rightarrow \mathrm{C}_{2} \mathrm{H}_{4}+\mathrm{H}$ & $\mathrm{k}=3.06 \times 10^{10}(\mathrm{~T})^{0.95} \exp (-36.9 / \mathrm{RT})$ & 33 \\
\hline
\end{tabular}

${ }^{\mathrm{a}}$ First order rate coefficient unit: $\mathrm{s}^{-1},{ }^{\mathrm{b}}$ Second order rate coefficient unit: $\mathrm{cm}^{3} \mathrm{~mol}^{-1} \mathrm{~s}^{-1}$

considered, because the reactant exists in large concentrations. The rate constant for this reaction is not available in the literature and therefore the rate constant for hydrogen abstraction reaction by methyl radical from methyl chloride was used. ${ }^{27}$ It was found that the $\mathrm{CH}_{3} \mathrm{CH}_{2} \mathrm{CH}_{2} \mathrm{Cl}$ consumption was insignificant. For the $\mathrm{CH}_{3}+\mathrm{CH}_{3} \mathrm{CH}_{2} \mathrm{CH}_{2} \mathrm{Cl}$ reaction, $\mathrm{H}$ abstraction mechanism is considered ${ }^{27}$ for the formation of methane in our simulations. In both methyl chloride and propylchloride, the $\mathrm{C}-\mathrm{Cl}$ bond $\left(\sim 83 \mathrm{kcal} \mathrm{mol}^{-1}\right)$ is weaker than the $\mathrm{C}-\mathrm{H}$ bond $\left(\sim 90-100 \mathrm{kcal} \mathrm{mol}^{-1}\right)$. It appears that abstraction of $\mathrm{Cl}$ will be important in these reactions, but we are not aware of any information considering this possibility. In our experiments, methyl chloride is not observed, and $\mathrm{CH}_{3}+\mathrm{CH}_{3} \mathrm{CH}_{2} \mathrm{CH}_{2} \mathrm{Cl}$ reaction do not seem to be contributing significantly. Reaction of $\mathrm{CH}_{3}$ with $\mathrm{CH}_{3} \mathrm{CH}=\mathrm{CH}_{2}$ and subsequent reactions are included for completeness, and their contribution to $\mathrm{CH}_{4}$ formation was observed to be very small. (R5, R14, R17, R18 and R25 also lead to the formation of $\mathrm{CH}_{4}$.) 3.2b Ethylene: Ethylene is the major product formed in the decomposition of 1-chloropropane in the studied temperature range. The major channel for the formation of ethylene is the $\mathrm{C}-\mathrm{Cl}$ bond dissociation in $\mathrm{CH}_{2} \mathrm{CH}_{2} \mathrm{Cl}$ radical.

$$
\begin{aligned}
\mathrm{CH}_{2} \mathrm{CH}_{2} \mathrm{Cl} & \rightarrow \mathrm{CH}_{2}=\mathrm{CH}_{2}+\mathrm{Cl} \\
\mathrm{k} & =3.9 \times 10^{13} \exp (-21.7 / \mathrm{RT})
\end{aligned}
$$

This reaction (R9) contributes about $70 \%$ of the formation of ethylene. The other channel via $\mathrm{CH}_{2} \mathrm{CH}_{2} \mathrm{Cl}$ radical decompose is the formation $\mathrm{CH}_{2}=\mathrm{CHCl}$ by leaving $\mathrm{H}$ atom (R21). However, we have not noticed the formation of vinyl chloride in the experiments, probably because of very low concentrations below the detection limits of both GC and FTIR instruments. The other important channel for the formation of ethylene is the reaction between two $\mathrm{CH}_{3}$ radicals.

$$
\begin{aligned}
\mathrm{CH}_{3}+\mathrm{CH}_{3} & \rightarrow \mathrm{CH}_{2}=\mathrm{CH}_{2}+\mathrm{H}_{2} \\
\mathrm{k} & =1 \times 10^{16} \exp (-32.0 / \mathrm{RT})
\end{aligned}
$$




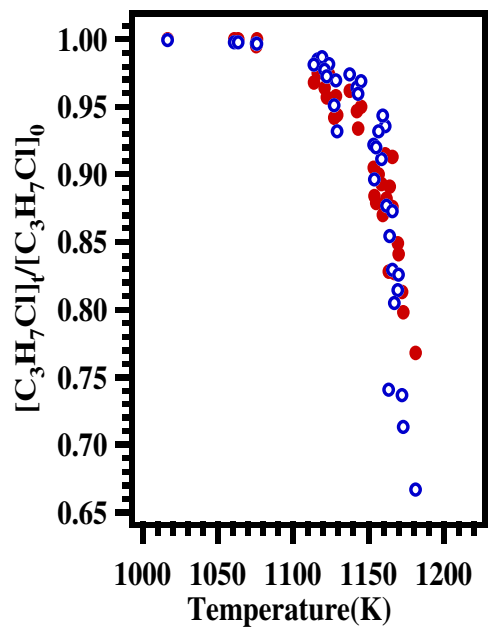

(a)

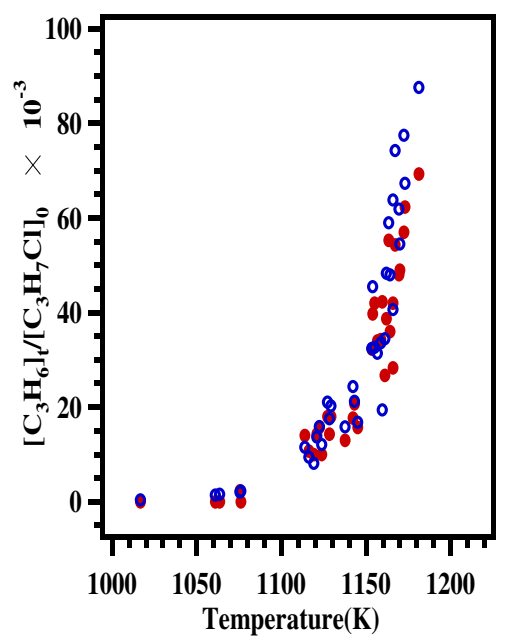

(c)

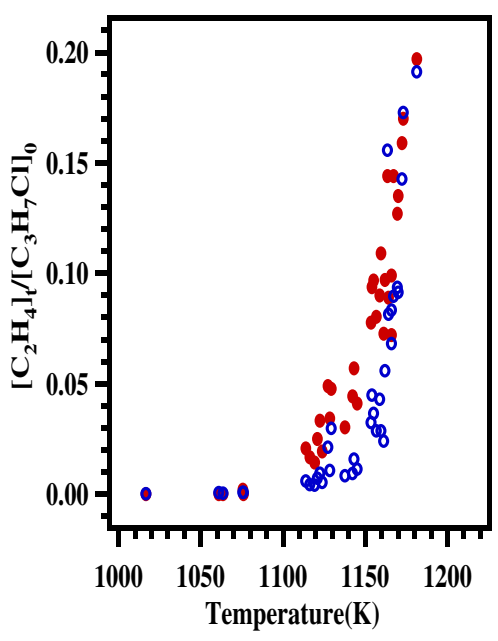

(b)

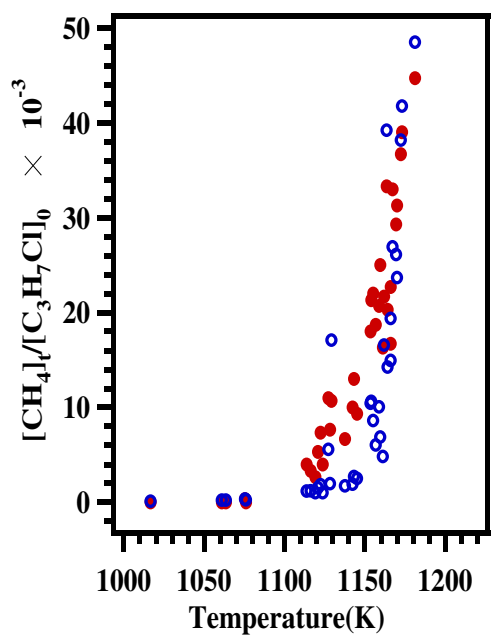

(d)

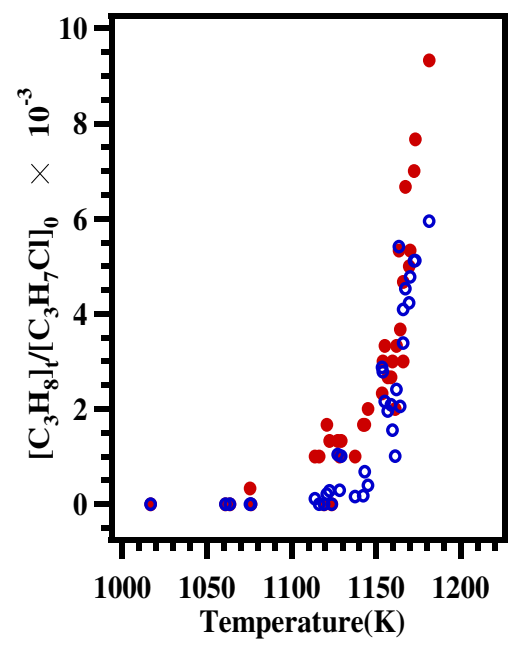

(e)

Figure 6. Comparison between the experimentally measured and simulated concentration profiles of (a) 1-chloropropane (b) ethylene (c) propylene (d) methane and (e) propane. Filled maroon circles on the plots are simulated concentrations and open blue circles are experimentally measured concentrations. 
R26 contributes to about $20 \%$ of the formation of ethylene. The other important channel is the decomposition of $\mathrm{CH}_{3} \mathrm{CH}_{2} \mathrm{CH}_{2}$ radical.

$$
\begin{aligned}
\mathrm{CH}_{3} \mathrm{CH}_{2} \mathrm{CH}_{2} & \rightarrow \mathrm{CH}_{2}=\mathrm{CH}_{2}+\mathrm{CH}_{3} \\
\mathrm{k} & =1.26 \times 10^{13} \exp (-30.4 / \mathrm{RT})
\end{aligned}
$$

$\mathrm{R} 4$ contributes to about $8 \%$ of the formation of ethylene. A minor channel for the formation of ethylene is the recombination of $\mathrm{C}_{2} \mathrm{H}_{5}$ and $\mathrm{CH}_{3}$ radicals. This reaction contributes to $2 \%$ of the ethylene formation.

$$
\begin{aligned}
\mathrm{CH}_{3} \mathrm{CH}_{2}+\mathrm{CH}_{3} & \rightarrow \mathrm{CH}_{2}=\mathrm{CH}_{2}+\mathrm{CH}_{4} \\
\mathrm{k} & =9.80 \times 10^{12}(\mathrm{~T})^{-0.5}
\end{aligned}
$$

3.2c Propane: Formation of propane was found at higher temperatures only (above $1110 \mathrm{~K}$ ). The only possible way in which propane can be formed is via the recombination of $\mathrm{CH}_{3}$ and $\mathrm{C}_{2} \mathrm{H}_{5}$ radicals.

$$
\begin{aligned}
\mathrm{CH}_{3}+\mathrm{CH}_{3} \mathrm{CH}_{2} & \rightarrow \mathrm{CH}_{3} \mathrm{CH}_{2} \mathrm{CH}_{3} \\
\mathrm{k} & =2.45 \times 10^{14}(\mathrm{~T})^{-0.5}
\end{aligned}
$$

Although the concentrations of $\mathrm{CH}_{3}$ and $\mathrm{C}_{2} \mathrm{H}_{5}$ radicals are significant, they are consumed mainly in the formation of methane and ethylene. Therefore, the availability of these radicals is limited to R16. The formation of acetylene and 1,2-dichloroethane is quite possible. However, they were not detected in both GC and FTIR, probably because of very low concentrations.

\subsection{Computational methods}

To complement our experimentally measured rate coefficient for the unimolecular elimination of $\mathrm{HCl}$, we have used density functional theory in combination with transition state theory to obtain the rate coefficient. The structure of the reactant $\left(\mathrm{CH}_{3} \mathrm{CH}_{2} \mathrm{CH}_{2} \mathrm{Cl}\right)$, transition states TS1, TS2 and products were optimized at B3LYP ${ }^{34,35}$ (Becke, 3-parameter, Lee-YangParr) functional with $6-311++\mathrm{G}^{* * 36,37}$ basis set, which are internally available in Gaussian 09 suite. ${ }^{38}$ Potential energy surface scan for $\mathrm{CH}_{3} \mathrm{CH}_{2} \mathrm{CH}_{2} \mathrm{Cl}$ molecule was carried out at B3LYP/6-311++G** level of theory and it was found that only one rotamer $\mathrm{R} 1$ exists for $\mathrm{CH}_{3} \mathrm{CH}_{2} \mathrm{CH}_{2} \mathrm{Cl}$ molecule. Two transition states TS1 and TS2 were found for the elimination of $\mathrm{HCl}$ from $\mathrm{CH}_{3} \mathrm{CH}_{2} \mathrm{CH}_{2} \mathrm{Cl}$ molecule. TS1 corresponds to elimination of $\mathrm{HCl}$ from the first hydrogen atom and TS2 corresponds to elimination of $\mathrm{HCl}$ from the second hydrogen atom of $\beta-\mathrm{CH}_{2}$ site in 1-chloropropane. Frequency analysis was carried out for the reactant, products and TSs at the same level of theory. The reactant and products were characterized with zero imaginary frequencies, and transition states were characterized with one imaginary frequency. The vibrational frequencies were not scaled and they were used as is in the calculation of the rate coefficients. G3B $3^{39}$ theory was used to calculate more precise barrier energy. Structural parameters obtained from B3LYP/6-311++G** were used for all energetic and kinetic calculations. The minimum energy path (MEP) was obtained by intrinsic reaction coordinate ${ }^{40}$ (IRC) calculations using B3LYP/6$311++\mathrm{G}^{* *}$ level of theory to verify that the transition states connect the designated local minima. It was also confined that both the transition states follow distinctly different potential paths.

\subsection{Computational results and discussions}

3.4a Structure and energetics: Two transition states, namely TS1 and TS2, were identified for the elimination of $\mathrm{HCl}$ from the $\mathrm{CH}_{3} \mathrm{CH}_{2} \mathrm{CH}_{2} \mathrm{Cl}$ molecule. TS1 and TS2 correspond to elimination of $\mathrm{HCl}$ from the $\beta-\mathrm{CH}_{2}$ and $\alpha-\mathrm{CH}_{2} \mathrm{Cl}$ in 1-chloropropane. A significant change in structural parameters of reactant was noticed while forming transition states. The leaving $\mathrm{C}-\mathrm{H}$ bond length in reactant (increased) seems to be varied up to a maximum of $13 \%$ and the leaving $\mathrm{C}-\mathrm{Cl}$ bond length (increased) was found to be varied up to a maximum of $32 \%$ in both the transition states structure. The variations of all the bond lengths while moving along the reaction coordinate from the reactant to the transition states are given in the supplementary information table S1. The structures of the reactant, transition states and products obtained at B3LYP/6-311++G** level of theory are shown in figure 7 , and all the optimized structural parameters and vibrational frequencies are given in supplementary information (table S2 and table S3).

The computed barrier heights for both the transition states are approximately equal and much higher in energy $\left(56.2 \mathrm{kcal} \mathrm{mol}^{-1}\right)$. These channels are less favourable at ambient conditions, but they will be dominant at higher temperatures. The barrier heights $\left(\Delta \mathrm{E}_{0}^{\neq}\right.$

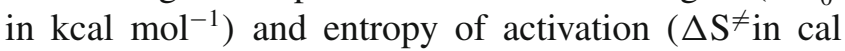
$\mathrm{mol}^{-1} \mathrm{~K}^{-1}$ ) obtained by the G3B3 theory are given in table 3. This conclusion is further confirmed by computing standard enthalpy change and Gibbs free energy change for these channels. The computed standard enthalpy change and Gibbs free energy change for the formation of products $\left(\mathrm{CH}_{3} \mathrm{CH}=\mathrm{CH}_{2}+\mathrm{HCl}\right)$ are $14.5 \mathrm{kcal} \mathrm{mol}^{-1}$ and $4.2 \mathrm{kcal} \mathrm{mol}^{-1}$, respectively. These channels are characterized as endothermic and less 


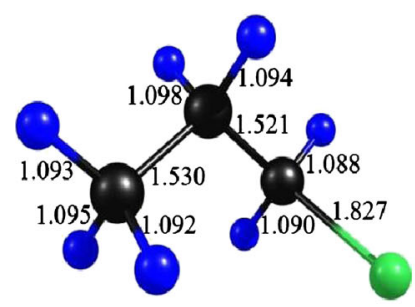

$\mathrm{CH}_{3} \mathrm{CH}_{2} \mathrm{CH}_{2} \mathrm{Cl}$

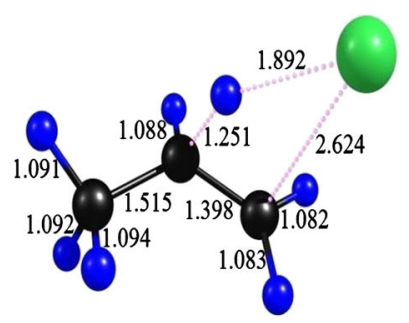

TS1

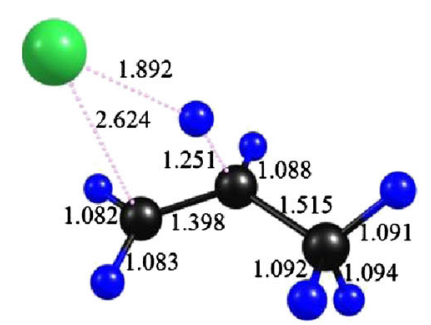

TS2

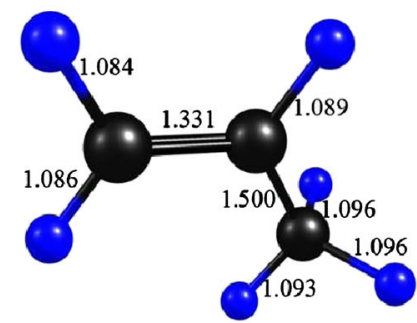

$\mathrm{CH}_{3} \mathrm{CH}=\mathrm{CH}_{2}$

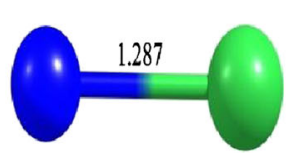

$\mathrm{HCl}$

Figure 7. Optimized structures of the reactant, transition states and products of 1-chloropropane at B3LYP/6-311++G** level of theory.

spontaneous at ambient conditions, based on these values. The obtained values of standard enthalpy change, standard free energy and standard entropy change for the elimination of $\mathrm{HCl}$ from 1-chloropropane at G3B3 theory are given in table S4 of the supplementary information. In addition, energies of all the optimized geometries were compared with the energies obtained from IRC calculations at B3LYP/6-311++G** level of theory. The energies are in good agreement with each other and the corresponding energies are given in table 4 . The IRC profiles corresponding to the transition states TS1 and TS2 are shown in figure 8, which shows two independent energy paths for the said channels.

3.4b Kinetic calculations: The energies and harmonic vibrational frequencies obtained at G3B3 theory and B3LYP/6-311++G** level of theory, respectively,

Table 3. Classical barrier heights $\left(\Delta \mathrm{E}_{0}^{\neq}\right.$in $\left.\mathrm{kcal} \mathrm{mol}^{-1}\right)$ and entropy of activation $\left(\Delta \mathrm{S}^{\neq}\right.$in cal $\left.\mathrm{mol}^{-1} \mathrm{~K}^{-1}\right)$ obtained from G3B3 level of theory.

\begin{tabular}{lll}
\hline & $\Delta \mathrm{E}_{0}^{\neq}$ & $\Delta \mathrm{S}^{\neq}$ \\
TS & $\mathrm{G} 3 \mathrm{~B} 3$ & $\mathrm{G} 3 \mathrm{~B} 3$ \\
\hline TS1 & 56.2 & 2.7 \\
TS2 & 56.2 & 2.7 \\
\hline
\end{tabular}

were used to calculate the temperature-dependent rate coefficients for the title reaction in the temperature range of $800-1500 \mathrm{~K}$. The following rate equation ${ }^{41}$ was used to calculate the rate coefficient.

$$
k(T)=l \frac{k_{B} T}{h}\left(\frac{Q_{\neq}}{Q_{R}}\right) \exp \left(-\frac{\Delta E_{0}}{R T}\right)
$$

Where $l$ is the statistical factor or reaction path degeneracy, $E_{0}$ is the zero point barrier height for the reaction, $\neq$ represents the transition state, $k_{B}$ is Boltzmann constant and h is Planck's constant. $Q_{\neq}$and $Q_{R}$ are the partition functions for transition state and reactant, respectively. The reaction path degeneracy $(l)$ for the studied reaction is 1 (one). The temperature-dependent rate coefficients were computed for every $25 \mathrm{~K}$ interval within the complete temperature range of 800-1500 K. These calculations were done for both transition states, namely TS1 and TS2. TST calculations were carried out to compute the rate coefficient using two models, namely harmonic oscillator (HO) model and free rotor (FR) model. The reduced moments of inertia for lower frequency, which was treated as free rotor, and the corresponding torsional barrier is given in table S5 of the supplementary information. Surprisingly, the energy barriers obtained by both the models are just the same, $58.8 \mathrm{kcal} \mathrm{mol}^{-1}$, which are very close to the reported ${ }^{5,9}$ barriers. However, the pre-exponential 
Table 4. Energies (Hartree) of reactant and products obtained in IRC calculations at B3LYP/6-311++G** level of theory.

\begin{tabular}{llccc}
\hline & \multicolumn{3}{c}{ Energies(Hartree) } \\
\cline { 2 - 3 } TS & & IRC & Individual species \\
\cline { 2 - 3 } & Reactant & Products & Reactant & Products \\
\hline TS1 & -578.719799 & -578.726399 & -578.710156 & -578.693708 \\
TS2 & -578.749791 & -578.709511 & -578.710156 & -578.693708 \\
\hline
\end{tabular}

factor obtained using the HO model is about $25 \%$ higher than that obtained by using the FR model. The computed rate parameters for the unimolecular elimination of $\mathrm{HCl}$ from 1-chloropropane at the G3B3 theory, using the $\mathrm{HO}$ and FR models in the studied temperature range, are given in table 5 .

\subsection{Comparison of kinetics parameters}

The kinetic parameters of the title reaction obtained experimentally and computationally in the present study are compared with the previously reported data and are given in table 6. Our experimentally determined pre-exponential factor is 1.7 times less when compared with the one reported by Barton et al. ${ }^{5} 1.9$ times less when compared with the one reported by Hartmann et al. ${ }^{6} 1.8$ times less when compared with Evans et al. ${ }^{7}$ 1.6 times less when compared with Okada et al. ${ }^{8}$ and one order less when compared with the one reported by Saheb. ${ }^{9}$ Similarly our experimentally measured activation energy is found to be higher by about 3-6 kcal

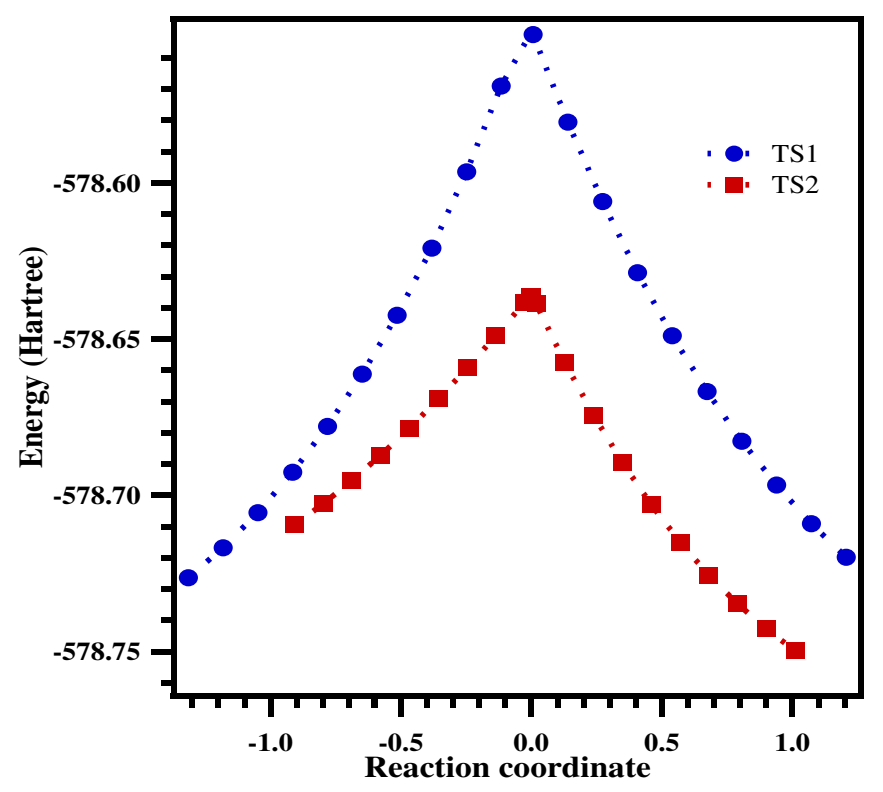

Figure 8. Energy level diagram obtained using Intrinsic Reaction Coordinate (IRC) calculations at B3LYP/6$311++\mathrm{G}^{* *}$ level of the theory. The IRC calculations were performed in 21 steps for two transition states, namely, TS1 and TS2. $\mathrm{mol}^{-1}$ when compared with the ones reported by Barton et al. ${ }^{5}$ Hartmann et al. ${ }^{6}$ Evans et al. ${ }^{7}$ Okada et al. ${ }^{8}$ and Saheb. ${ }^{9}$ Also the theoretically obtained pre-exponential factor is found to be one order higher when compared with previously ${ }^{5-8}$ reported data, as well as our experimental data and it is in reasonable agreement with the pre-exponential factor reported by Saheb. ${ }^{9}$ On the other hand, the theoretically estimated energy barrier is in reasonably good agreement with the ones reported by Barton et al. ${ }^{5}$ Hartmann et al. ${ }^{6}$ Evans et al. ${ }^{7}$ Okada et al. ${ }^{8}$ and Saheb, ${ }^{9}$ considering the reported error bars. Also the energy barriers estimated both by the $\mathrm{HO}$ and FR models are in excellent agreement with our experimentally determined one. It should be noted here that, while our experimentally determined pre-exponential factors are comparable with the reported experimental values, the theoretically computed pre-exponential factors are higher by about an order of magnitude. The pre-exponential factor depends mainly on the partition functions of both the reactant and transition states, which in turn depends on the vibrational frequencies. Therefore, the computed pre-exponential factor mainly depends on how accurately they are determined. Hence, we attribute this difference to the closest possible extent that the used B3LYP functional could determine the vibrational frequencies. As mentioned earlier, the energies of both the reactant and transition states were further refined with the G3B3 theory. Therefore, the energy barriers obtained in our theoretical calculations are very close to both our experimental findings and the ones reported earlier. An Arrhenius plot with all the experimentally measured and theoretically computed rate coefficients in our study is given in figure 9. All the previously reported data are also appended in this figure 9 for comparison.

As mentioned in the chemical thermometric method, cyclohexene was used as an internal standard. The rate

Table 5. Comparison of the rate parameters obtained for the unimolecular $\mathrm{HCl}$ elimination from 1-chloropropane.

\begin{tabular}{lcc}
\hline Method & $A\left(\mathrm{~s}^{-1}\right)$ & $\mathrm{E}_{\mathrm{a}}\left(\mathrm{kcal} \mathrm{mol}^{-1}\right)$ \\
\hline G3B3 (FR) & $(5.01 \pm 0.06) \times 10^{14}$ & 58.8 \\
G3B3 (HO) & $(6.64 \pm 0.16) \times 10^{14}$ & 58.8 \\
\hline
\end{tabular}


Table 6. Comparison of Arrhenius parameters for the unimolecular elimination of $\mathrm{HCl}$ from 1-chloropropane.

\begin{tabular}{|c|c|c|c|c|}
\hline S.NO & $\begin{array}{c}\text { Temperature } \\
\text { Range }(\mathrm{K})\end{array}$ & $\mathrm{A}\left(\mathrm{s}^{-1}\right)$ & $\mathrm{E}_{a}\left(\mathrm{kcal} \mathrm{mol}^{-1}\right)$ & References \\
\hline 1 & $1015-1220$ & $1.63 \times 10^{13}$ & $(60.1 \pm 1.0)$ & This experimental work \\
\hline 2 & $800-1500$ & $(5.01 \pm 0.12) \times 10^{14}$ & $(58.8)$ & This theoretical work \\
\hline 3 & $693-751$ & $(2.82 \pm 0.98) \times 10^{13}$ & $(57.0 \pm 1.2)$ & 5 \\
\hline 4 & $672-734$ & $(3.16 \pm 0.66) \times 10^{13}$ & $(55.1 \pm 0.7)$ & 6 \\
\hline 5 & $960-1100$ & $(3.09 \pm 0.74) \times 10^{13}$ & $(54.4 \pm 1.1)$ & 7 \\
\hline 6 & $990-1100$ & $(2.75 \pm 0.68) \times 10^{13}$ & $(54.8 \pm 1.2)$ & 8 \\
\hline 7 & $200-2000$ & $(3.16 \pm 0.00) \times 10^{14}$ & $(59.7)$ & 9 \\
\hline
\end{tabular}

coefficient for the decomposition of cyclohexene into 1, 3-butadiene and ethylene reported by both Tsang ${ }^{11}$ and Stranic et al. ${ }^{12}$ were used in the calculation of the reflected shock temperatures. We have noted a difference of $28 \mathrm{~K}$ between the reflected shock temperatures calculated using Tsang ${ }^{11}$ and Stranic's ${ }^{12}$ rate expressions. However, this difference may be neglected, as the errors reported by Stranic et al. ${ }^{12}$ are in the range of $19-36 \%$ in their rate coefficient. In any case, the rate coefficients obtained by using both the rate expressions are plotted in figure 9. The experimentally determined and theoretically computed rate coefficients (G3B3-FR model) are fit to the Arrhenius equation and they are $\left.\mathrm{k}=1.63 \times 10^{13} \exp \left(-(60.1 \pm 1.0) \mathrm{kcal} \mathrm{mol}^{-1} / \mathrm{RT}\right)\right) \mathrm{s}^{-1}$ and $\left.\mathrm{k}=(5.0 \pm 0.1) \times 10^{14} \exp \left(-(58.8) \mathrm{kcal} \mathrm{mol}^{-1} / \mathrm{RT}\right)\right)$

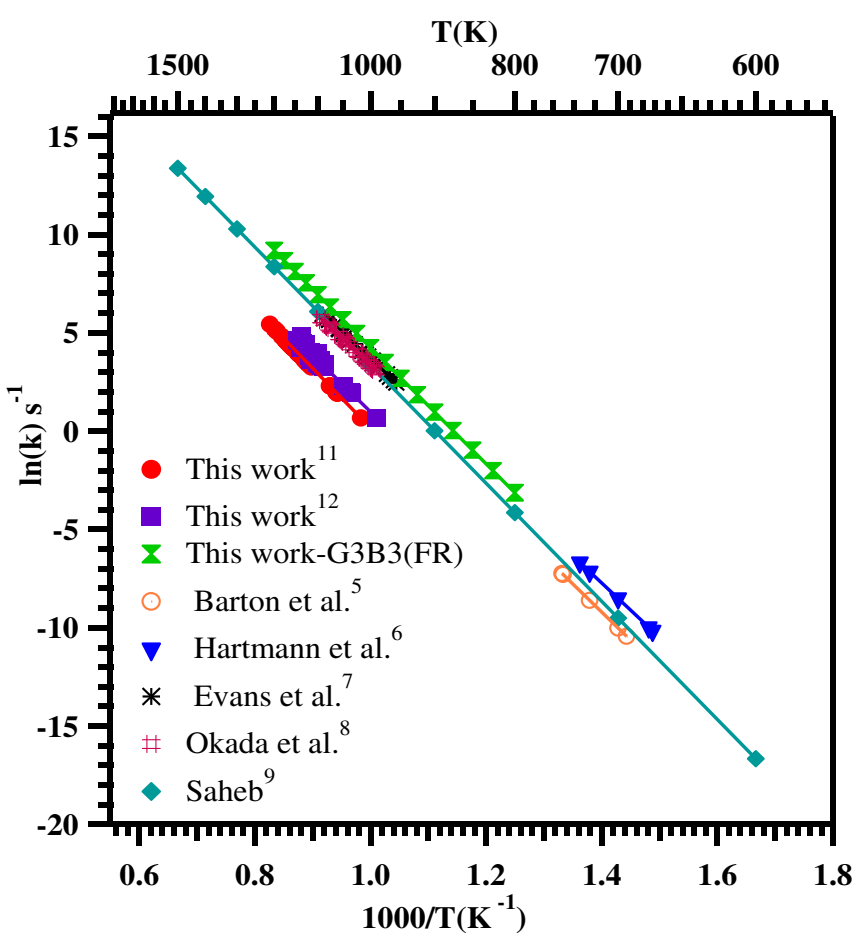

Figure 9. The Arrhenius plot for the thermal decomposition of Unimolecular elimination of $\mathrm{HCl}$ reaction from 1-chloropropane. The available kinetic parameters are also added in this figure for comparison. $\mathrm{s}^{-1}$ respectively. It is clear from the plot that the trends (slopes) obtained are similar to the previously reported rate coefficients. However, the intercept due to theoretical data on $\mathrm{y}$-axis $(\ln (\mathrm{k}))$, which are essentially the preexponential factor is different by an order of magnitude as discussed earlier.

\section{Conclusions}

The Single Pulse Shock Tube has been constructed in our laboratory and was used to study the complete decomposition of 1-chloropropane over the temperature range of $1015-1220 \mathrm{~K}$. Although the major reaction channel is unimolecular elimination of $\mathrm{HCl}$ from 1-chloropropane to form propylene, $\mathrm{C}-\mathrm{Cl}$ and $\mathrm{C}-\mathrm{C}$ bond dissociation have played an important role in forming other products like methane, ethylene and propane. Kinetic simulations were carried out using proposed reaction scheme. The results obtained from simulations are in reasonably good agreement with experimentally measured values. DFT calculations were also carried out for the unimolecular elimination of $\mathrm{HCl}$ from 1-chloropropane. The obtained experimental and theoretical kinetic parameters are found to be in good agreement with the previously reported studies.

\section{Supplementary Information}

The electronic supplementary information (tables S1, S2, S3, S4 and S5) can be seen at www.ias.ac.in/ chemsci.

\section{Acknowledgements}

We acknowledge the financial support from Council of Scientific \& Industrial Research (CSIR), India, for establishing the Single Pulse Shock Tube. We thank Mr. V Ravichandran of High Performance Computing Environment Facility for his valuable support, Mr. A Parandhaman for his help in the experiments 
and Mr. M Balaganesh for fruitful discussions. Mr. G Balaganesan of central workshop is acknowledged for the workshop support in the establishment of the shock tube facility.

\section{References}

1. Graham J L, Hall D L and Dellinger B 1986 Environ. Sci. Tech. 20703

2. Oppelt E T 1987 J. Air Pollut. Control. Assoc. 37558

3. Yang M, Karra S B and Senkan S M 1987 Hazard. Waste. Hazard. Mater. 455

4. Hart J R and Franco G 1989 Proceedings of the Third Symposium on the Incineration of Hazardous Wastes, Paper 15, San Diego, CA

5. Barton D H R, Head A J and Williams R J 1951 J. Chem. Soc. 2039

6. Hartmann H, Bosche H G and Heydtmann H 1964 Z. Phys. Chem (Neue Folge). 42329

7. Evans P J, Ichimura T and Tschuikow-Roux E 1978 Int. J. Chem. Kinet. 10855

8. Okada K, Tschuikow-Roux E and Evans P J $1980 \mathrm{~J}$. Phys. Chem. 84467

9. Saheb V 2013 Struct Chem. DOI 10.1007/s11224013-0240-2

10. Gaydon A G and Hurle I R 1963 The shock tube in high temperature chemical physics, (New York: Reinhold Publishing)

11. Tsang W 1965 J. Chem. Phys. 421805

12. Stranic I, Davidson D F and Hanson R K 2013 Chem. Phys. Lett. 58418

13. Tsang W, Walker J A and Braun W 1982 J. Phys. Chem. 86719

14. Karra S B and Senkan S M 1988 Ind. Eng. Chem. Res. 27447

15. Warnatz J 1984 In Combustion Chemistry (ed.) W C Gardiner Jr. (New York: Springer-Verlag)

16. Tsang W 1985 J. Am. Chem. Soc. 1072872

17. Forst W 1991 J. Phys. Chem. 953612

18. Tsang W 1988 J. Phys. Chem. Ref. Data. 17887

19. Lloyd A C 1971 Int. J. Chem. Kinet. 339

20. Barat R B and Bozzelli J W 1992 J. Phys. Chem. 96 2494

21. Roussel P B, Lightfoot P D, Caralp F, Catoire V, Lesclaux R and Forst W 1991 J. Chem. Soc. Faraday Trans. 872367

22. Hidaka Y, Nakamura T, Tanaka H, Jinno A and Kawano H 1992 Int. J. Chem. Kinet. 24761

23. Knyazev V D, Bencsura A, Stoliarov S I and Slagle I R 1996 J. Phys. Chem. 10011346
24. Tsang W 1991 J. Phys. Chem. Ref. Data. 20221

25. Lifshitz A, Tamburu C and Suslensky A 1990 J. Phys. Chem. 942966

26. Arthur N L and Bell T N 1978 Rev. Chem. Intermed. 2 37

27. Macken K V and Sidebottom H W 1979 Int. J. Chem. Kinet. 11511

28. Knyazev V D, Kalinovski I J and Slagle I R 1999 J. Phys. Chem. A. 1033216

29. Stewart P H, Larson C W and Golden D M 1989 Combust. Flame. 7525

30. Garrett B C and Truhlar D G 1979 J. Am. Chem. Soc. 1015207

31. Bryukov M G, Slagle I R and Knyazev 2001 J. Phys. Chem. A. 1053107

32. Kern R D, Singh H J and Wu C H 1988 Int. J. Chem. Kinet. 20731

33. Curran H J 2006 Int. J. Chem. Kinet. 38250

34. Becke A D 1993 J. Chem. Phys. 985648

35. Lee C, Yang W and Parr R G 1986 Phys. Rev. B. 37785

36. Francl M, Pietro W J, Hehre W J, Binkley J S, Gordon M S, Defrees D J and Pople J A 1982 J. Chem. Phys. 77 3654

37. Frisch M J, Pople J A and Binkley J S 1989 J. Chem. Phys. 803265

38. Frisch M J, Trucks G W, Schlegel H B, Scuseria G E, Robb M A, Cheeseman J R, Scalmani G, Barone V, Mennucci B, Petersson G A, Nakatsuji H, Caricato M, Li X, Hratchian H P, Izmaylov A F, Bloino J, Zheng G, Sonnenberg J L, Hada M, Ehara M, Toyota K, Fukuda R, Hasegawa J, Ishida M, Nakajima T, Honda Y, Kitao O, Nakai H, Vreven T, Montgomery J A, Jr, Peralta J E, Ogliaro F, Bearpark M, Heyd J J, Brothers E, Kudin K N, Staroverov V N, Keith T, Kobayashi R, Normand J, Raghavachari K, Rendell A, Burant J C, Iyengar S S, Tomasi J, Cossi M, Rega N, Millam J M, Klene M, Knox J E, Cross J B, Bakken V, Adamo C, Jaramillo J, Gomperts R, Stratmann R E, Yazyev O, Austin A J, Cammi R, Pomelli C, Ochterski J W, Martin R L, Morokuma K, Zakrzewski V G, Voth G A, Salvador P, Dannenberg J J, Dapprich S, Daniels A D, Farkas O, Foresman J B, Ortiz J V, Cioslowski J and Fox D J 2010 Gaussian 09, Revision B.01, Gaussian, Inc., Wallingford CT

39. Curtiss L A, Redfern P C, Raghavachari K, Rassolov V and Pople J A 1999 J. Chem. Phys. 1104703

40. Gonzalez C and Schlegel H B 1989 J. Chem. Phys. 90 2154

41. Wright M R 1999 Fundamental Chemical Kinetics: An Explanatory Introduction to the Concepts (Horwood Series in Chemical Science) (UK: Woodhead Publishing) 